\title{
182 Reviews
}

changed, with the passing decades. But more explicitly, the editor's introduction also offers a concise history of the Canadian Historical Review (CHR), the premiere historical journal in Canada. Here, although Professor Shore has previously written on similar subjects, the introduction falls a bit short.

My complaint is that the introduction is a simple narrative, revealing few glimpses of discussions behind the scenes. Perhaps the CHR's double-blind assessment process prevents revealing too much, but surely this could be accommodated. Simply put, the introduction glosses over contentious issues and is largely uncritical. As one example, although Shore repeatedly informs the reader that the editors tried to bridge the divide between French and English Canadians, it is difficult to perceive just how this was tried prior to the Quiet Revolution. The CHR remained firmly English in its conception, only awakening to the other solitude in the 1950s under John Saywell. Its first Frenchlanguage article, appearing in 1962, was a curiously political choice - Fernand Ouellet's analysis of the historical roots of Québécois separatism - that reflected Anglophone apprehensions about Quebec and Canada more than Frenchlanguage scholarship of the day. All of this receives little comment from Shore.

There are other examples that reflect, not so much a contested past, but an exercise in consensus building. This is not the fault of Marlene Shore. It would have been irresponsible to portray, for instance, a tradition of bilingualism where none really existed. But silences can be deafening, and informative. Where were the rebels and outsiders in this story? Were there no dissatisfied contributors? The CHR may be open to new methods today, but it is unfortunate that Shore does not explore the politics behind editorial decisions of the past. Editors and editorial boards sometimes have agendas (as might reviewers) and the rejected might reveal more than the published. An analysis of the reasons given for rejecting submissions, or perhaps some figures on the kinds of papers and authors most often turned down, might have revealed a greater but hidden contest to frame our collective memories. This is not investigated in the book Marlene Shore has given us. Instead we are shown a past contested, but only within the general consensus of mainstream academic historians.

Alan Gordon

University of Guelph

David Brandenberger, National Bolshevism: Stalinist Mass Culture and the Formation of Modern Russian National Identity, 1931-1956 (Cambridge and London: Harvard University Press, 2002).

David Brandenberger's National Bolshevism focuses on history and historical narrative as key to understanding how a particular national identity was creat- 
ed in Russia under Joseph Stalin.

The work is divided into three chronological periods. Part one looks at the development of a "national Bolshevism" up to the eve of World War II. Part two focuses on ideology during the war years. Part three analyses the post-war period up to the death of Stalin. Brandenberger argues that, constantly concerned with insuring the legitimacy of the Soviet state and of the inability of a "marginally educated citizenry" to understand Marxist-Leninism, "Stalin and his colleagues gradually refashioned themselves as etatists and began to selectively rehabilitate famous personalities and familiar symbols from the Russian national past" (8). According to Brandenberger, because "the population largely failed to grasp" the more philosophical elements of the party narrative which was really designed to promote patriotic loyalty to party and state, the approach taken toward "popular mobilization ultimately contributed to no less than the formation of a mass sense of Russian national identity in Soviet society" (9).

Brandenberger provides a well-written, coherent background chapter on the weak sense of national identity that existed in the Tsarist and early Soviet period. He argues that most Russians lacked a sense of common heritage and history. For Brandenberger, the 1927 war scare was the warning for the Soviet regime that it needed a coherent sense of identity around which to mobilize popular support. In order to achieve such mobilization, he argues, the party ideologues had to turn to "more conventional styles of agitation oriented around the promotion of individual heroes, patriotism, and history itself" (27).

Brandenberger argues that the "Great Terror" destabilized the "pantheon" of Soviet heroes who had been credited with the establishment of the Soviet Union and precipitated a shift to Russian and pre-Revolutionary heroes and to the idea of the Russian people as the vanguard of the Soviet nation. He describes this shift as an "about face," from "proletarian internationalism to national Bolshevism" (44-45). Brandenberger's choice of "national Bolshevism" is obviously a carefully considered one. It would have enriched the work to see a more detailed discussion of the various evocations the term obviously conjures. Brandenberger does discuss M. N. Riutin's use of the term (6-7), but there is no mention of the concept as it appeared in other places and contexts or of the wink to "national Socialism."

Brandenberger traces the development and presentation of history through the war years, noting that there were "both quantitative and qualitative differences about Russian and non-Russian themes that placed the former in a privileged position vis-à-vis the latter"(157). He discusses the increasing conflation of notions of "Russian" and "Soviet" over time. More reflection on the matter would have been welcome. In some cases, even after the war, some writers do seem to be making a deliberate choice of one word over the other in a particular context. There are many moments in which Brandenberger's work hints at a spectrum of nuance and variation but then shies away from delving too 


\section{Reviews}

deeply into such contradictions.

Contradictions, however, are at the center of his discussion of post-war ideology. Brandenberger wrestles with the question of whether or not the emphasis on the Russian national past is "eclipsed by the myth of the war" (187). He concludes that "starting in the mid-1940s, two epics informed Soviet state legitimacy until the USSR's collapse in 1991: a thousand years of prerevolutionary Russian history and its complement, the 'Soviet' experience of the war" (192). He views the period of the zhdanovshchina as "the culmination of a nativist drive that had been steadily russifying the Soviet ideological experience since 1937" (196).

In each section of his book, Brandenberger takes on the laudable and extremely challenging question of the popular reception of state ideology. He provides a rare look into the understanding of history on the part of Russian primary school children. Although extremely difficult to explore in the confines of a single project, a comparison between Russian speaking children's interpretation and those of similar-aged children in Ukraine or Kazakhstan, for example, would have been fascinating. Throughout the work, the reader catches glimpses of the wider exigencies of life in the Soviet Union. In a chapter on public and party education (or lack thereof) in the post-war period, for example, the chair of an urban party committee explained to visiting officials that his knowledge and understanding of party ideology were weak because they really were not relevant to his day-to-day work. Brandenberger also includes some of the shortcomings in the understanding of history and ideology among staff members in the Ministry of State Security.

Brandenberger makes impressive use of a vast array of sources from the historical works produced in Stalin's Soviet Union and rich and varied archival collections, to lectures, broadcasts, diaries, newspapers, films, opera, schoolchildren's essays, museum guest books, exhibits, and exhibitions. He has a broad and impressive knowledge of an extensive secondary literature in a variety of languages. The work is careful, detailed, and exhaustively referenced.

Brandenberger's study raises many questions and issues for further debate and research. In a multi-ethnic, gendered, and classed society one wonders how these matters played out in the pages of history textbooks. There are intriguing moments in which Brandenberger compares the portrayal of various groups within the Soviet fraternity. How were workers and peasants portrayed in the pages of history under Stalin? How were intellectuals cast? Did the recasting of history contain within its pages an agenda for the creation of a certain kind of Soviet boy or girl, man or woman? There is a notable absence of Catherine the Great from the pantheon: speculation as to why this was the case may have proved rewarding. Using the interviews of the Harvard University Refugee Interview Project, Brandenberger illustrates that interviewees noticed that revolutionary heroes became enemies overnight. Was the regime able to overcome 
this distrust?

Finally, perhaps Brandenberger pushes his arguments about russocentrism too far. He acknowledges tensions, contradictions, and dualities among notions of internationalism and of russocentrism. Perhaps these contradictions and dualities would have made an interesting and revealing focus.

Still, the book is an ambitious and extensive study which provides a major contribution to the surprisingly understudied and insufficiently understood, yet crucial theme of ideology under Stalin, especially through the war years and beyond. His presentation of the controversy and scandal surrounding the History of the Kazakh SSR and of the Short Course on the History of the USSR are fascinating. Brandenberger is to be highly commended for wrestling through an enormous amount of extremely varied material and shaping it into a coherent and accessible argument and study.

Tracy McDonald

McMaster University

Peter Ives, Gramsci's Politics of Language: Engaging the Bakhtin Circle and the Frankfurt School (Toronto: University of Toronto Press, 2004).

The last 30 years have seen an explosion of writings on Antonio Gramsci in almost all social science and humanities disciplines - so much so that short of fresh applications of a 'Gramscian' method to the study of specific contexts, one might conclude there is little new to say about Gramsci's thought itself. Yet a newly adapted theoretical reading of Gramsci's ideas is exactly what Peter Ives strives to present in Gramsci's Politics of Language. What results is not just another book on Gramsci, but rather a unique reading of Gramsci's work through a wide-ranging interdisciplinary engagement with history, linguistics, and Marxist philosophies of language, culture, and social and political thought. Ives investigates the connection between Gramsci's linguistic and political concepts by simultaneously explaining the way they relate internally throughout Gramsci's thought, historically contextualizing the linguistic debates Gramsci had with his contemporaries, and bringing his particular reading of Gramscian political and linguistic philosophy into a theoretical dialogue with the works of other influential (but unknown to Gramsci) Marxist theorists of the era.

The book's overarching argument focuses on proving that the ideas Gramsci developed in his early training in linguistics and his engagements with Italian language politics, are complementary to (and influenced) the cultivation of his better known contributions - hegemony, organic intellectuals, the war of manoeuvre/war of position, the philosophy of praxis - more commonly asso- 